\title{
Social Media Da'wah Literacy on the West Java Saber Hoaks Program
}

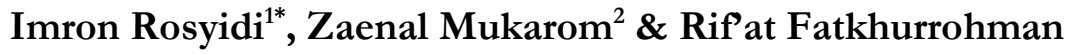 \\ Jaelani $^{3}$ \\ ${ }^{123}$ UIN Sunan Gunung Djati Bandung, Indonesia \\ *imron.rosyidi@uinsgd.ac.id
}

\begin{abstract}
Hoax or false information is a problem and one of the impacts of the unwise use of social media. The spread of hoaxes on social media can potentially break the unity and trigger religious conflict. In response to these problems, West Java Saber Hoaks was formed to suppress and prevent the spread of hoaxes on social media. The purpose of this study is to reveal: (1) Jabar Saber Hoaks' efforts in countering hoaxes; and (2) literacy of social media da'wah by Jabar Saber Hoaks. This study uses a case study method with a qualitative approach. Based on the study results, the following findings were found: (1) There were four efforts made by West Java Saber Hoaks in preventing hoaxes, namely opening a complaint service, monitoring content that has the potential to be a hoax, clarifying information, and providing literacy. (2) Social media da'wah literacy by West Java Saber Hoaks is carried out through preventive measures and information verification. From the results of this study, there are significant and recommendations, namely: (1) There is a need for mainstreaming social media literacy. (2) There is a need for preventive da'wah efforts on social media to ward off hoax information.
\end{abstract}

Keyword: Jabar Saber Hoaks; social media literacy; preventive da'wah.

\begin{abstract}
ABSTRAK
Hoaks atau false information merupakan problematika dan salah satu dampak yang ditimbulkan dari penggunaan media sosial yang kurang bijak. Penyebaran hoaks di media sosial dapat berpotensi memecah persatuan dan memicu konflik keagamaan. Menyikapi persmasalahan tersebut, Jabar Saber Hoaks dibentuk untuk menekan dan menangkal penyebaran hoaks di media sosial. Tujuan dari studi ini ialah untuk mengungkap: (1) Upaya Jabar Saber Hoaks dalam menangkal hoaks; dan (2) Literasi dakwah media sosial oleh Jabar Saber Hoaks. Studi ini menggunakan metode studi kasus dengan pendekatan kualitatif. Berdasarkan hasil studi, didapatkan temuan berikut: (1) Ada empat upaya yang dilakukan Jabar Saber Hoaks dalam menangkal hoaks, yaitu membuka layanan aduan, memantau konten yang beprotensi hoaks, mengklarifikasi informasi dan memberikan literasi. (2) Literasi dakwah media sosial oleh Jabar Saber Hoaks dilakukan dengan cara upaya preventif dan verifikasi informasi. Dari hasil studi ini ada signifikasi dan rekomendasi, yaitu: (1) Perlu adanya mainstreaming literasi media sosial. (2) Perlu adanya uapaya dakwah preventif di media sosial untuk menangkal informasi hoaks.

Kata kunci : Jabar Saber Hoaks; literasi media sosial; dakwah preventif.
\end{abstract}

Received: Januari 2021. Accepted: Maret 2021. Published: Juni 2021 


\section{INTRODUCTION}

The development and progress of social media in the era of disruption have a positive impact in terms of communication and information and have a negative impact. Microsoft's most actual research results in February 2021 revealed that Indonesian netizens were the most disrespectful netizens in Southeast Asia (Ikhsan, 2021). The research results indicate that there is a significant problem to be analyzed, discussed, and conducted in a more comprehensive study to obtain practical solutions in problemsolving efforts.

The phenomenon of netizens' impoliteness is not the only problem caused by the negative impact of using social media in Indonesia. Based on observations, several problems are caused by the unwise use of social media, such as cybercrime, hate speech, and hoaxes. All problems in social media lead to the spread of untrue information (fake news), which we commonly know as hoax information.

The impact of hoaxes on social media is very much felt, as Lokananta \& Herlina (2018) revealed that the impact of spreading hoaxes on social media could trigger conflict. Even Legionosuko \& Harnowo (2017) revealed that fake news or hoaxes were a source of horizontal conflict in the 2017 DKI Provincial Election. In addition, Septanto (2018) also stated that hoax news on social media could divide unity and damage harmony and tolerance. In social life in society. On the other hand, Rustandi and Muchtar (2020) emphasize that hoax information on social media is often used as a space that leads to the indoctrination of intolerant, radical behavior and virtual terrorism. Dewi and Triandika (2020) emphasize the importance of digital media literacy to counter hoax, hate speech, and radical terrorism narratives. Furthermore, Fakhruroji, Rustandi, and Busro (2020) explained that the construction of religious language on social media could be used as an alternative in countering hoax narratives and manipulative and provocative information.

Based on the phenomena and problems of hoax information on social media that hurt the wider community, it is necessary to prevent or suppress the spread of hoax information on social media. If the suppression, deterrence, and prevention of hoax information are not immediately carried out, the impact will be that more and more people are "eaten" by the hoax news. Its excesses can lead to social conflict and national disintegration. 
Responding to the hoax problem on social media, one of the efforts made by the Government through the Ministry of Communication and Information (Kominfo) is to form an "Anti-Hoaks Task Force" since 2017 (Fakta, 2017). Apart from the Anti-Hoaks Task Force, when the incessant hoax news became a national issue, many institutions, communities, agencies, and organizations were formed that were concerned with efforts to suppress and prevent hoax news. According to the results of the Dwinanda study (2019), the main task of the Anti-Hoaks Task Force, the National Cyber Agency, and other similar institutions is that in addition to preventing hoax news, they also have a role in enforcing criminal law against the spread of hoaxes on social media.

Efforts to prevent hoaxes on social media are also carried out in Indonesia, including in West Java. The West Java Provincial Government specifically created the "Jabar Saber Hoaks" program to suppress the spread and prevent the spread of hoax news in various media, especially social media. This program was formed based on the Decree of the Governor of West Java No. 7000.05/Kep.12161-Diskominfo/2018 regarding the West Java Hoaks Saber Team for West Java Province. Functionally, this team has the primary task and function of verifying information or rumors that are not yet clear, developing, and spreading in the community. Procedurally, information verification by this team is carried out by confirming and compiling, and analyzing data from various sources or references that are actual and credible.

The existence, function, and contribution of the West Java Saber Hoaks program are fundamental and need to be studied further. This study on West Java Saber Hoaks has an urgency to reveal the role and function of West Java Saber Hoaks comprehensively to suppress and prevent hoaxes which are the actual problems at this time. This study on the West Java Saber Hoaks is very actual and relevant because, during the incessant hoax information circulating on social media, this study can at least reveal efforts to suppress and prevent hoax information that can be done practically and procedurally.

Today's hoax problem has become a national problem that can threaten the harmony and unity of the Indonesian people with a high level of heterogeneity and plurality. From an Islamic perspective, Abd. Wahid (2017) and Maulana (2017) equate the definition of the hoax with kadzib, which is a lie. Referring to several verses of the Qur'an, people who lie are wicked. Based on this, it can be seen that hoaxes and their spreaders are 
harmful and dangerous and includes a big sin. Even in a review (shari'ah) of Islamic law, Nasution (2017) mentions hoaxes as a form of hudud.

Hoak's prevention efforts carried out by Jabar Saber Hoaks, if analyzed from the perspective of Islamic da'wah, is one form of da'wah that is very actual and factual in the era of social media. The effort to prevent hoaxes on social media is an actual realization of the concept of Amar ma'ruf and nahi Munkar in da'wah activities. In the context of Amar ma'ruf and nabi Munkar, West Java Saber Hoaks commits nabi Munkar by verifying, clarifying, and confirming hoax news spread on social media. The efforts made by West Java Saber Hoaks are a preventive measure in da'wah to prevent the spread of false news (kadzib). Efforts to nabi Munkar Jabar Saber Hoaks include the most actual da'wah. They are needed by the community today because, according to Aziz \& Santoso (2020), nahi Munkar is more indispensable in developing Islamic da'wah than Amar ma'ruf.

The main functions and tasks of West Java Saber Hoaks are in preventing and countering hoax news on social media, including da'wah activities carried out through the internet. West Java Saber Hoaks da'wah activities to nabi Munkar by preventing hoaxes are carried out online through social media, such as on the website: https://saberhoaks.jabarprov.go.id; Instagram account: @jabarsaberhoaks; and Facebook fan page: @official.jabarsaberhoaks. About Islamic da'wah carried out through social media, Moch. Fakhruroji (2017) called this phenomenon Da'wah in New Media, while Rustandi (2019) termed it Cyberdakwah and Mukarom, Rosyidi \& Muzzamil (2020) called it Mediatization of Da'wah.

Observing and analyzing da'wah activities on social media to ward off hoaxes carried out by West Java Saber Hoaks is essential to conduct theoretical and practical studies. This study on West Java Saber Hoaks, apart from being able to reveal the problems of hoaxes on social media, can also lead to literacy efforts for social media da'wah, which have not been widely studied and carried so far out in practice. Therefore, a study on social media da'wah literacy in the West Java Saber Hoaks program is significant. It aims to find out practical steps to prevent hoaxes on social media through da'wah literacy. The fact is that social media's problems and negative impacts affect various aspects of life, from social, cultural, political to religion. So the study of Social Media Da'wah Literacy in the West Java Saber Hoaks Program is essential to carry out. 
The primary purpose of this study is to reveal the steps of Jabar Saber Hoaks in countering hoax news on social media. Assessed from the perspective of Islamic da'wah, the efforts made by West Java Saber Hoaks include the form of nahi Munkar through social media. Furthermore, studied from a communication perspective, the steps taken by Jabar Saber Hoaks can also be a kind of literacy tool for social media users to be wiser in disseminating information content, especially information containing religious content.

The study of social media literacy as an effort to prevent hoaxes is not new. Based on the results of a literature review, many previous studies have examined efforts to prevent hoaxes on social media through Islamic da'wah activities social media literacy. Among the results of previous studies that have relevance to this study are studies conducted by Thadi $\&$ Mukhlizar (2021), Mazaya (2019), Tsaniyah \& Juliana (2019), and Octalia \& Mughni (2018). The five results of the previous study are relevant to the study of social media da'wah literacy in the West Java Saber Hoaks program. The relevance lies in understanding social media literacy to suppress and prevent hoaxes from spread on social media.

The preliminary study only focused on examining, analyzing, and uncovering efforts to prevent hoaxes by understanding general and normative social media literacy. These studies are not focused on the subject of study or the object of study precisely. Therefore, this study has a distinctive element in the study subject, specifically devoted to the West Java Saber Hoaks program as a work unit team under the West Java Provincial Government, which has the main task of verifying information containing hoaxes. Apart from the aspect of the subject of the study, this study also has a distinction with other similar studies, especially in the object of study, which uses a da'wah perspective and approach in analyzing and observing the phenomenon of preventing hoaxes through social media literacy. This study will try to more comprehensively review and analyze the problems of hoaxes and social media literacy from the perspective of Islamic da'wah. The two elements of the distinction, namely the subject of study in the form of West Java Saber Hoaks and the object of the study analyzed using a comprehensive da'wah perspective, are expected to be novel (novelty), so it is hoped that the results of this study can contribute to similar da'wah institutions, organizations, and institutions. To provide social media literacy to suppress and prevent hoaxes that can divide unity and trigger religious conflicts. 
Methodologically, this study uses the case study method. A case study is a research method that investigates, traces, and closely observes a program, event, activity of an organization, institution, or group of individuals (Mukarom, 2020: 6). The case study method was used to trace and investigate the efforts made by West Java Saber Hoaks in countering hoaxes through social media literacy da'wah. The program, event, or activity he observes is proselytizing social media literacy to prevent hoaxes, while the organization or institution is West Java Saber Hoaks. In terms of approach, this study uses a qualitative approach. The study using a qualitative approach aims to understand the phenomenon of what is experienced and done by the subject of the study. In practice, the study will try to understand more profoundly and analyze more comprehensively the phenomenon of preventing hoaxes by West Java Saber Hoaks from the perspective of Islamic da'wah.

This study has significance in revealing the steps or efforts of social media da'wah literacy carried out by Jabar Saber Hoaks in winning hoax information on social media. The results of this study are expected to contribute to similar institutions, da'wah practitioners, and social media activists as reference materials and guidelines in carrying out social media da'wah literacy, significantly to suppress the spread and prevention of massive hoax information on social media.

\section{RESULT AND DISCUSSION}

\section{Jabar Saber Hoaks Efforts in Countering Hoaxes}

Observing and analyzing the Jabar Saber Hoaks official website, it can be seen that Jabar Saber Hoaks make at least four efforts in countering hoax information spread on various social media platforms. The four efforts are: (1) West Java Saber Hoaks responds directly to complaints from the public regarding content that contains hoaxes; (2) West Java Saber Hoaks monitors the flow of information traffic on social media, which is indicated to contain hoaxes; (3) West Java Saber Hoaks provides clarification on a piece of information based on factual and credible sources; and (4) West Java Saber Hoaks provides literacy to the public by posting journals, articles, and information containing knowledge values.

The four efforts to prevent hoaxes were obtained from an analysis of the "Jabar Saber Hoaks Service" menu on the West Java Saber Hoaks official website. Here is an overview of the Jabar Saber Hoaks service menu: 
Figure 1. West Java Saber Hoaks Service Menu

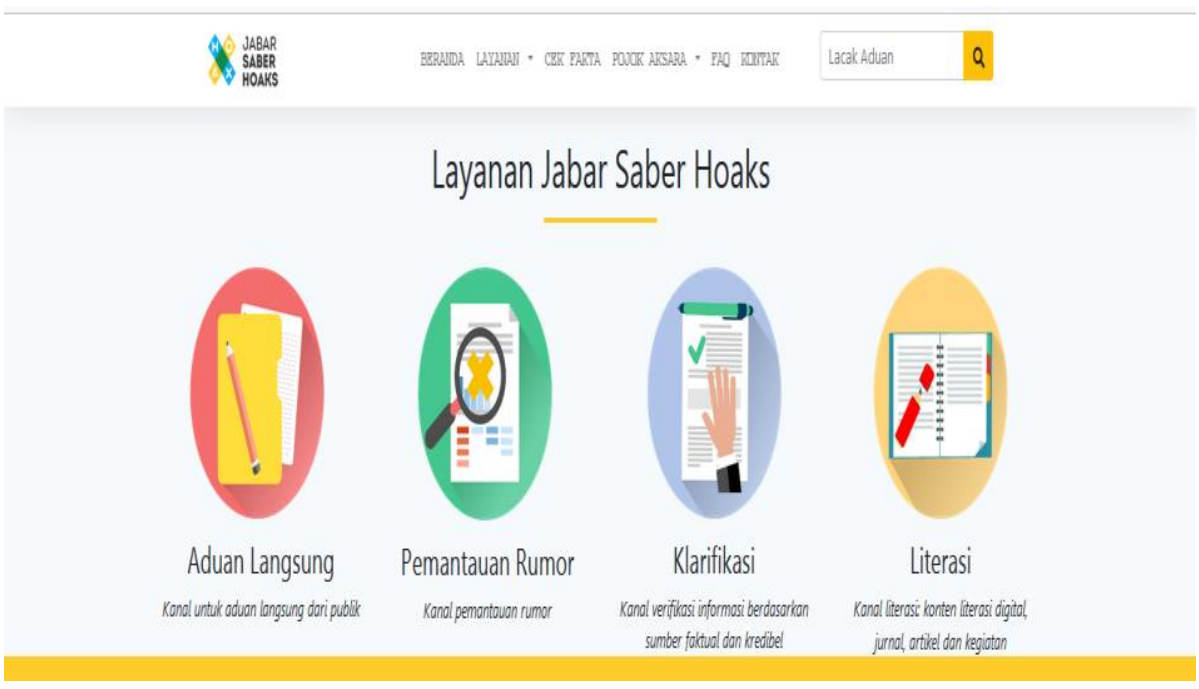

Source: West Java Saber Hoaks Website, 2021

Figure 1 shows procedural information about the Jabar Saber Hoaks service menu. Based on observations on the service menu, it can be said that West Java Saber Hoaks make four efforts in preventing hoaxes from spread on social media. A comprehensive and in-depth observation of the four efforts resulted in several significant findings related to the West Java Saber Hoaks efforts. In more detail, the findings of the study are explicitly described in the discussion of four hoax prevention efforts carried out by West Java Saber Hoaks, namely:

First, West Java Saber Hoaks responds directly to complaints from the public regarding content that contains hoaxes. This first effort is the earliest effort made by West Java Saber Hoaks in preventing hoaxes. Jabar Saber Hoaks responsively responds to various complaints sent through the public's direct complaint service menu on the website. Various complaints have been entered on the West Java Saber Hoaks website, especially information that is not necessarily true and news containing elements of lies. The West Java Saber Hoaks Team will immediately process all incoming complaints by verifying and confirming the news indicated to contain hoaxes. After the verification process is complete, whether the information is a fact or a hoax will be known. The following is an overview of the statistical data for complaints submitted to West Java Saber Hoaks until June 8, 2021, 18:00 WIB: 
Figure 2. Statistical Data for West Java Saber Hoaks Complaint Service

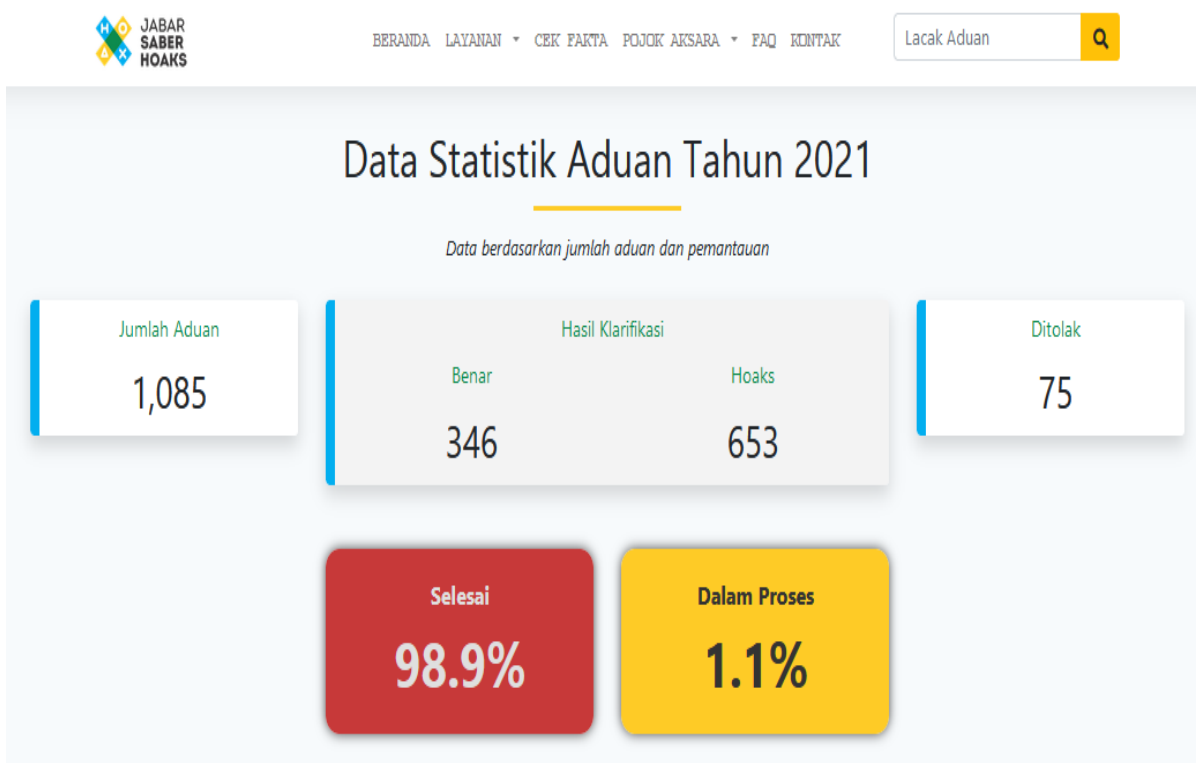

Source: West Java Saber Hoaks Website, 2021

Based on the statistical data in Figure 2 above, it can be seen that until June 8, 2021, there were a total of 1,085 complaints from the public. This number represents that there is still a lot of information content containing hoaxes scattered on various social media. The results of the clarification reinforce this fact carried out by the West Java Saber Hoaks Team. Where the results show that more than half of the total number of complaints are hoaxes. Overall, the responsive and clarifying efforts made by the West Java Saber Hoaks Team through this direct complaint service were considered very effective. The efforts made by West Java Saber Hoaks can suppress the spread of hoax information on social media, which irresponsible or unwise social media users often spread.

Second, West Java Saber Hoaks monitors the flow of information traffic on social media, which contains hoaxes. On the official website of West Java Saber Hoaks, this effort is on the service menu with the title "Rumors Monitoring." Practically, this effort provides information to the public about monitoring news or information indicated to contain hoaxes. Through this rumor-monitoring effort, the West Java Saber Hoaks Team conducted an analysis and identification of various information and issues that could cause "commotion" in the community. An important finding 
from this effort is that there is a post on June 30, 2021, on the website and Instagram of Jabar Saber Hoaks, which is unique and exciting. The post is in the form of an image with the title "Anatomy of a Hoax Spreader's Tongue." The picture contains information about things that have the potential to spread hoax information. Here is the image post:

Figure 3. Unique Posts Containing Appeals

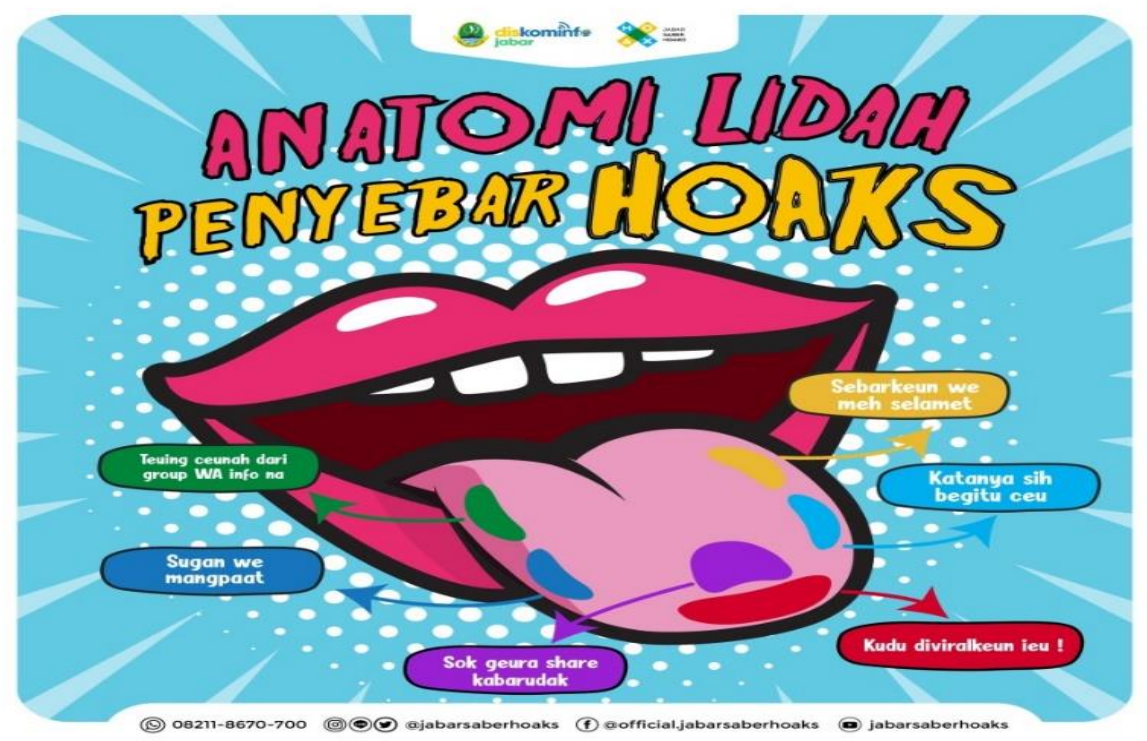

Source: IG West Java Saber Hoaks, 2021

It is interesting to observe picture 3 above. There are some texts in Sundanese contained in the picture. If translated into Indonesian, the Sundanese text is an utterance or statement that can spread hoax information. Here is the Indonesian translation of the text in the picture: teuing ceunah dari group $W A$ info na (don't know, the information is from the WA group), sugan we manpaat (hopefully it will be useful), sok gera share ka barudak (quickly spread it to other people) others), kudu diviralkeun ieu (this must be viral), katanya sib begitu ceu (he said so ma'am), sebarkeun weh meh selamat (just spread it to be safe). I understood from the contents of the text message. This is an effort to appeal to the West Java Saber Hoaks Team not to post and disseminate information that is not necessarily true or news that is not necessarily useful. This effort is effortless to understand, especially for the people of West Java. Moreover, it is packaged using the 
local language.

Third, West Java Saber Hoaks provides clarification of information based on factual and credible sources. In this effort, complaints from the community are verified and confirmed until they are clarified. Among the several findings regarding this clarification, some hoax information was spread and developed on social media, which West Java Saber Hoaks successfully clarified. Based on the division of the period, from 2018 to 2019, there were five clarification periods carried out by West Java Saber Hoaks. The following is the clarification period through the table below:

Table 1 Clarification Period for Hoax News by West Java Saber Hoaks

\begin{tabular}{|c|c|c|c|}
\hline \multicolumn{2}{|r|}{ Period } & Hoax & Clarification \\
\hline $\begin{array}{l}\text { Period } \\
2018\end{array}$ & 24-30 December & $\begin{array}{l}\text { Information circulating } \\
\text { about Kyai Ma'ruf Amin } \\
\text { wishing you a Merry } \\
\text { Christmas wearing Santa } \\
\text { Claus clothes }\end{array}$ & $\begin{array}{l}\text { Based on the results of the } \\
\text { investigation by the West } \\
\text { Java Saber Hoaks team, the } \\
\text { video circulating is not the } \\
\text { real thing. }\end{array}$ \\
\hline January & 11, 2019 period & $\begin{array}{l}\text { Hoaks- Scenario Ahok } \\
\text { replaces KH Ma'ruf Amin } \\
\text { in the first year. }\end{array}$ & $\begin{array}{l}\text { In response to this, the } \\
\text { Twitter account of the } \\
\text { National Police Public } \\
\text { Relations Division } \\
\text { clarified. The Police Public } \\
\text { Relations Division stated } \\
\text { that the news was not } \\
\text { accurate. It is not valid or a } \\
\text { hoax. Bogor Palace is } \\
\text { closed to the public. Then } \\
\text { the photo uploaded by the } \\
\text { account is in the Bogor } \\
\text { Botanical Gardens, and the } \\
\text { fee is the Bogor Botanical } \\
\text { Gardens, not the Bogor } \\
\text { Palace. }\end{array}$ \\
\hline $\begin{array}{l}\text { Period } \\
2019\end{array}$ & January & $\begin{array}{l}\text { Based on reports of } \\
\text { complaints that went to the } \\
\text { WA JSH admin, a quote } \\
\text { from BJ Habibie circulated, } \\
\text { saying, "Prabowo's } \\
\text { formidable opponent is not } \\
\text { Jokowi if only Jokowi An } \\
\text { easy way for Pak Prabowo } \\
\text { to lead the next period in } \\
2019 \text {. }\end{array}$ & $\begin{array}{l}\text { After the West Java Saber } \\
\text { Hoaks team searched for } \\
\text { issues circulating recently } \\
\text { on social media, a narrative } \\
\text { entitled "BJ Habibie, if his } \\
\text { mind is sound, Prabowo." } \\
\text { The Habibie Center } \\
\text { confirmed it was a hoax. }\end{array}$ \\
\hline
\end{tabular}




\begin{tabular}{llll}
\hline Period 19-25 January & The hashtag 10 & After the West Java Saber \\
2019 & yearschallenge I am Jewish. & $\begin{array}{l}\text { Hoaks team conducted a } \\
\text { search related to the 10- } \\
\end{array}$ & $\begin{array}{l}\text { year challenge that I } \\
\text { thought was Jewish, it was } \\
\end{array}$ \\
& Hoak's information.
\end{tabular}

Source: JSH Official Media, 2021

Fourth, West Java Saber Hoaks provides literacy to the public by posting journals, articles, and information containing knowledge values. This last effort is the main focus of the object of this study, namely, about social media literacy carried out by West Java Saber Hoaks in preventing hoaxes. At the practical level, this literacy effort is carried out by conveying various information in journals, articles, news, and other short information that contains knowledge that is beneficial to the community. Contents about social media literacy can be accessed on the "Pojok Aksara" menu on the West Java Saber Hoaks website. On the "Akasara Corner" menu, there are five other menu options. Contents containing information and knowledge to provide social media literacy to the public can also be seen on the Jabar Sabar Hoaks Instagram and Facebook accounts. The following is one of the information contained in the literacy menu on the West Java Saber Hoaks website:

Figure 4. Information in the Literacy Menu

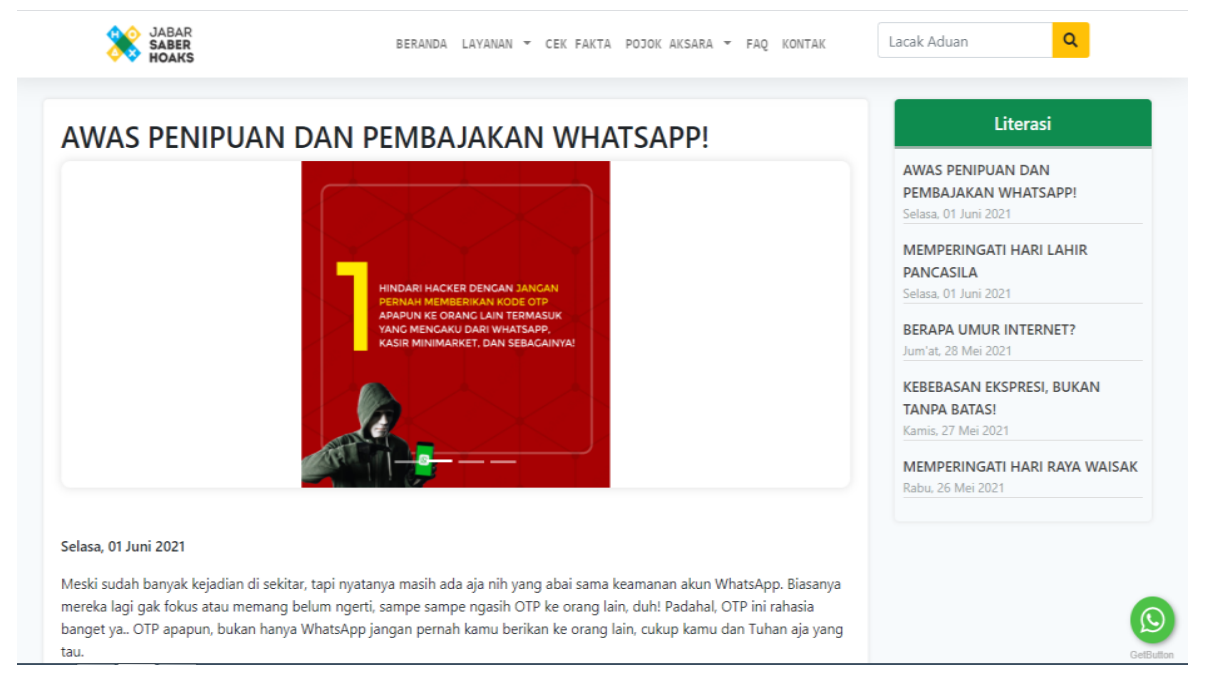

Source: West Java Saber Hoaks Website, 2021.

Ilmu Dakwah: Academic Joumal for Homiletic Studies 15(1) (2021) 81-102 
In addition to the Literacy menu on the website, social media literacy efforts from West Java Saber Hoaks are also carried out through social media Facebook and Instagram. If you open the Jabar Saber Hoaks Instagram account, you will find many posts that provide information and education about the world of social media. Here is the Jabar Saber Hoaks Instagram account:

Figure 5. Jabar Saber Hoaks Instagram Account

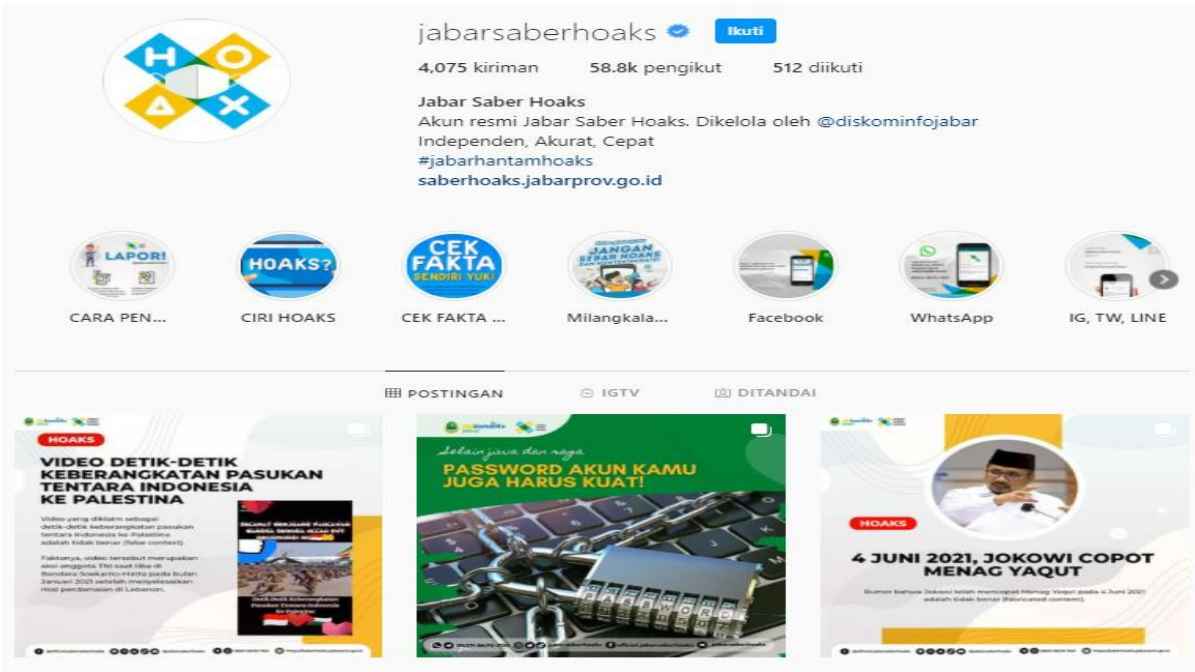

Source: Jabar Saber Hoaks Instagram Account, 2021

Figure 5 attempts to analyze the literacy menu on the website and all posts on the Jabar Saber Hoaks Instagram account. From this, it can be seen that West Java Saber Hoaks is very focused and concerned about preventing hoaxes by providing literacy and knowledge to the public through messages that are packaged in a unique, exciting, and easy to understand way. In terms of packaging the message, the content of the message is also very actual and factual, following updates on issues and information developing in the community. For example, lately, there is a lot of hacking and fraud with asking for an OTP code. Responding to this phenomenon, Jabar Saber Hoaks quickly posted information containing literacy about OTP codes for users of certain social media or applications. In the end, this literacy effort is an effort that must be continuously developed and intensified because there are still many social media users who are not technology literate. 
The four efforts to prevent hoaxes by West Java Saber Hoaks above show that their efforts are more preventive. Prevention from the start is an effort to suppress and anticipate the spread of hoax information on social media. Opening service for complaints, monitoring, clarification, and literacy is a preventive effort to prevent the public from obtaining and disseminating information that contains hoaxes. In literacy efforts, the West Java Saber Hoaks Team wants to provide preventive measures to the public with information and messages containing knowledge about actual and factual social media developments. This is done so that people can be more technologically literate and wiser in using social media.

The era of disruption is marked by a flood of information on various social media platforms. One of the pieces of information that must be addressed critically is a hoax. Jabar Saber Hoaks, through the four preventive steps above, tries to build a critical culture against the spread of hoax news. This is because a critical attitude is critical in dealing with the flood of destructive information such as hoaxes (Tsaniyah \& Juliana, 2019). Therefore, critical identification skills will lead to efforts to clarify information on social media. In this case, the construction of a critical attitude carried out by Jabar Saber Hoaks through its official media aims to make the public aware of the use of social media. One way to identify is by presenting knowledge references that can confirm the information obtained (Juditha, 2019).

West Java Saber Hoaks cannot be separated from the political will of the West Java Provincial Government in preventive efforts and safeguarding national integration. In this case, the government as a formal actor must ensure regulation, formal education, and establish various community forums in digital education efforts (Adila, Weda \& Tamitiadini, 2019). The government, as a formal actor, must build synergy with community partners. The West Java Saber Hoaks movement, which not only provides information, clarification, identification, and confirmation of justification but also shows that there are efforts to build strategic partnerships with non-formal actors. Strengthening government regulations through criminal law enforcement and blocking specific sites is evident to strengthen digital literacy in Indonesia (Ramayanti \& Sa'diyah, 2017). Both formal and non-formal actors are oriented towards critical and open awareness movements in digital technology to impact the integrity of the nation and the harmony of the Indonesian people.

Literacy culture and the internet awareness movement wisely become 
a force that can instill a critical mentality, affirmation, and confirmation of the spread of hoaxes (Fitriani, 2020). Therefore, strengthening reading libraries and library attendance can be used as one of the strengthening infrastructures in preventing hoaxes. Literacy culture is a strengthening of awareness and improvement of human dignity in the era of information disruption (Oktovianny, 2020). Therefore, strengthening this literacy culture must be carried out as an effort to counter hoax narratives while at the same time filling cyberspace with helpful information. One of them is through the spread of religious language, which is constructed in a popular, innovative, open, and democratic manner to strengthen users' theological and sociological awareness amid demands for technological skills (Fakhruroji, Rustandi \& Busro, 2020). In this case, West Java Saber Hoaks builds literacy awareness as part of efforts to disseminate information that can awaken the human side of its users.

\section{Social Media Da'wah Literacy by Jabar Saber Hoaks}

This discussion is more focused on describing the results of the analysis of the literacy efforts carried out by Jabar Saber Hoaks from the perspective of Islamic da'wah. About this social media literacy effort, it was found that there were three classifications of false information based on the analysis of the West Java Saber Hoaks Team. From the Jabar Saber Hoaks website, information is displayed about the "3 Types of False Information": misinformation, disinformation, and malinformation. Based on this information, it can be understood that there are three types of false information, namely: (1) Misinformation; (2) Disinformation; (3) Malinformation. For more details, here is information about three types of false information according to the Jabar Saber Hoaks classification: 
Figure 6. Three Types of False Information According to West Java Saber Hoaks

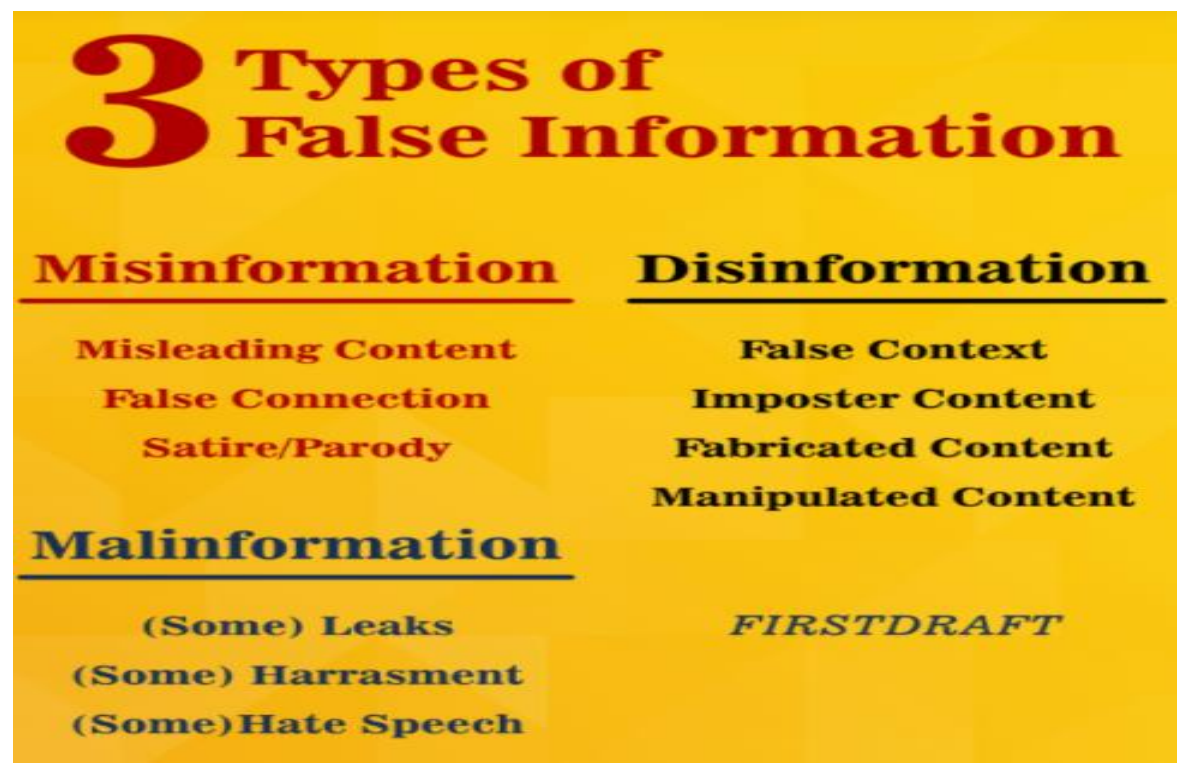

Source: West Java Saber Hoaks Website, 2021

From Figure 6 above, it can be seen that of the three types of false information classified by the West Java Saber Hoaks Team, each has its characteristics. Therefore, if the three classifications of false information are described in detail, it can be seen as follows:

First, misinformation with message characteristics: (1) misleading content (misleading message); (2) false connection (false information network); (3) satire/parody (information containing satire or parody). Second, disinformation with message characteristics: (1) false context (information that does not fit the context); (2) imposter content (incorrect information); (3) fabricated content (information that is intentionally fabricated); (4) manipulated content (manipulated information). Third, malinformation with message characteristics: (1) leaks (information containing data leaks); (2) harassment (information containing harassment); (3) hate speech (information containing hate speech).

The three types of false information - misinformation, disinformation, and malinformation - practically have the meaning of information, messages, or news that are wrong and not necessarily true, or what is more popularly known as hoaxes. Theoretically, the three terms 
have different definitions. Misinformation is false and inaccurate information that is spread to the public even though it is not intended to deceive and harm others; while disinformation is erroneous information and made to be disseminated to the public to harm others; and malinformation is information that does have a truth value, but the way it is presented and disseminated is packaged to harm others (Silalahi \& Sevilla, 2020; Khosiah \& Rohmiati, 2019). Thus, it can be said that the essence of this hoax is "information or message" that is disseminated to a broad audience through various media.

The message or information (message) in various contexts of communication and Islamic da'wah becomes a significant entity because the success of a communication process and da'wah activity is very dependent on the message it conveys. Specifically, in the terminology of da'wah science, messages or information conveyed in da'wah activities are called maudu (Pohan, Jamil, \& Andyna, 2017). About this da'wah maudu, in general, there are three types of da'wah maudu delivered in da'wah activities, namely: aqidah, shari'ah, and mu'amalah (Hidayat, 2018). Furthermore, maudu or da'wah messages conveyed to the public must contain the following three criteria, namely: informational message, instructional message, and motivational message (Ilaihi, 2010: 99).

Maudu must be true, actual, factual, accurate, and valuable information. In carrying out da'wah activities and in the context of social life, it is strictly prohibited and even prohibited to convey maudu, which is sourced from false information, fake news, fabricated, or not necessarily accurate. In the Qur'an in Surah Al-Hujurat [49] verse 6, it is ordered to do tabayun if you receive information (which is not necessarily true) brought by a fasiq. Therefore, the tabayun process becomes essential and cannot be separated to prevent and counter hoax information, mainly if the hoax contains religious information.

Tabayun itself can practically be interpreted to seek and examine the truth of any information, statement, or news. Another term for tabayun with tahqiq, namely an effort to find al-Haq (truth) (Chittick, 2007: 7). Tabayun and tabqiq are what in the language of communication is called verification and clarification of information. Verification of this information becomes very important in various aspects of life, especially in communication and da'wah through social media. In journalistic studies, verification is an essential element of the Nine Elements of Journalism proposed by Kovach \& Rosenstiel (Harnita, 2015). The West Java Saber 
Hoaks Team uses this verification effort in preventing and preventing the spread of hoks on social media.

Verification carried out by the West Java Saber Hoaks Team focused on three types of false information as described previously. So it is in this information verification effort, the position of West Java Saber Hoaks becomes critical to conduct tabayun on information that is not necessarily true. Based on the results of the analysis, it can be found that West Java Saber Hoaks carry out two types of verification to prevent hoaxes on social media, namely:

First, verify the content. Classify the verified hoax content. For example, it separated any content, including politics, SARA, Health, natural disasters, and international cases. It made a list of hoax content that is considered viral based on statistical data that the West Java Saber Hoaks team has processed. According to Iwan, the hoax content that has the most interaction and verification is political content. The steps taken by West Java Saber Hoaks in this classification are (1) collecting the total number of complaints submitted within one week; (2) classifying incoming complaints based on West Java Saber Hoaks social media; and (3) create a daily incoming complaint graph to see the percentage of the number of public or netizen responses to the fact verification results of the West Java Saber Hoaks team that meet the requirements and have not been verified.

Second, verify the facts. Verifying facts with the following stages: The first stage is information that can be hoaxes received by the Admin Team, both from the results of monitoring from social media, Instagram, Facebook, Twitter, WhatsApp, public complaints reports, and the Governor's Instructions. In the second stage, the information will be verified by the Fact-Checking Team to detect the truth. To assist Jabar Saber Hoaks in verifying this data, it is assisted with several tools, including social media monitoring software, hoax analyzer, standard operating procedures (SOP), database access for work units, provincial government agencies, and agencies as well as community and volunteer networks. Verification is intended to see if the news that is informed is old news or new news, the credibility of the information source, the content of the information, and other sources supporting the information obtained. The fact-finding team's references are based on mainstream media, government agencies, agencies, police, BMKOS, MUI.

In the third stage, the Fact-Finding Team will then provide information/verification of the circulating information. The fourth stage is 
then given to the Admin Team or the Dissemination Team. Then the admin team will process the verification of the information in the form of infographics and videographics in the form of verification and approving content, which is then published on the Jabar Saber Hoaks social media account. According to Iwan, the most dominant complaints received by West Java Saber Hoaks were content about politics, religion, security with a range of around 50 to 60 percent.

Observing the effort to verify the information, it can be concluded that the critical key to preventing this hoax is to provide information literacy to netizens so that they continue to do tabayun when getting information that is not yet clear with posts in the form of images containing informative messages, educative articles and short news about knowledge about social media literacy. Social media literacy carried out by Jabar Saber Hoaks can be said to be a da'wah effort in the context of nahi Munkar to prevent the spread of false news (kadzib) that can harm Muslims and society in general. Thus, it is stated that social media literacy carried out by West Java Saber Hoaks as an effort to preach nahi Munkar is by verifying information. The verified information is information that is indicated to contain hoaxes.

Preventive efforts by instilling a critical attitude and verifying information in tabayun become the power of da'wah literacy on social media. Therefore, da'wah on social media is a space for constructing a religious language that can attract audiences in the form of narratives, texts, graphics, videos, and other creative products (Fakhruroji, Rustandi \& Busro: 2020). Information literacy as a da'wah effort on social media can be done in the process of access, evaluation, and creation (Henriette \& Windiani, 2018). Both in the stages of access, evaluation, and creation, all three are carried out by prioritizing a critical culture (tabayun) in receiving information and efforts to disseminate it.

Da'wah literacy on social media can be done by constructing Islamic da'wah through popular thinking, popular communication processes, rituals or popular activities, and popular symbols (Rustandi \& Muchtar, 2020). In this case, the preventive steps and efforts to verify content and facts by Jabar Saber Hoaks are carried out in a widespread manner, adjusted to the trend of interest and trends of social media users in Indonesia. This is the effort of nabi Munkar as a da'wah activity that can arouse the spirit of spreading positive and productive content as da'wah messages in cyberspace. 


\section{CONCLUSION}

In summary, there are two significant findings in this study, namely: First, there are four efforts made by Jabar Saber Hoaks in preventing hoaxes, namely: opening a complaint service, monitoring potential content, clarifying information, and providing social media literacy. Second, social media da'wah literacy by West Java Saber Hoaks is carried out through preventive measures and information verification. In the context of Islamic da'wah, this preventive effort is an actual realization of nabi Munkar, and information verification is an actual implementation of tabayun and tahqiq.

Referring to the findings and conclusions of the study, at least some things become the significance and recommendations of the results of this study, namely: First, there needs to be a more massive mainstreaming of social media literacy, so that social media users - netizens can use media more wisely. Social media as a medium of information, communication can even be a medium of da'wah. Second, there is a need for preventive da'wah efforts on social media to suppress and prevent hoaxes, especially those related to Islamic information that can harm Muslims and the general public. In the end, the results of this study are expected to contribute to the development of da'wah science, especially da'wah activities on social media.

\section{REFERENCES}

Adila, I., Weda, W., \& Tamitiadini, D. (2019). Pengembangan Model Literasi dan Informasi Berbasis Pancasila dalam Menangkal Hoaks, Wacana, 18(1), 101-111. DOI: https://doi.org/10.32509/wacana.v18i1.721.

Aziz, A., \& Santoso, B. R. (2020). Nahi Mungkar dalam Dakwah (Konstruksi Hadits Dakwah terhadap Pengembangan Dakwah). Tasamuh, 18 (2): 190-210. DOI: https://doi.org/10.20414/tasamuh.v18i2.2766.

Chittick, W. C. (2007). Kosmologi Islam dan Dunia Modern: Relevansi Ilmu-Imu Intelektualisme Islam. Bandung: Mizan.

Dwinanda, R. A. (2019). Penegakan Hukum Pidana terhadap Penyebaran Berita Bohong di Media Sosial. Jurnal Panorama Hukum, 4 (2): 114-123. DOI: https://doi.org/10.21067/jph.v4i2.3902.

Fakhruroji, M. (2017). Dakwah di Era Media Baru. Bandung: Simbiosa Rekatama Media.

Fahruroji, M., Rustandi, R., \& Busro. (2020). Bahasa Agama di Media Sosial: Analisis Framing pada Media Sosial "Islam Populer", Jurnal Bimas Islam, 13(2), 203-234. DOI: https://doi.org/10.37302/jbi.v13i2.294. 
Fakta, T. C. (2017, Januari 12). Pemerintah Bentuk Satgas Anti-"Hoaks". Retrieved Juni 7, 2021, from Kompas: https://nasional.kompas.com/read/2017/01/12/18043621/pemerint ah.bentuk.satgas.anti-.hoaks.

Fitriani, S. (2020). Perpustakaan dan Gerakan Sadar Literasi sebagai Upaya Menangkal Hoaks, El-Pustaka: Jurnal Ilmu Perpustakaan dan Informasi Islam, $1(1), \quad 30-40 . \quad$ DOI: https://doi.org/10.24042/el\%20pustaka.v1i1.6724.

Harnita, P. C. (2015). Elemen Jurnalistik: Untuk Blogger. Jurnal Interaksi, 4 (1): 8289.

Henriette, S. C., \& Windiani, R. (2018). Pemberdayaan Literasi Media dan Informasi (LMI) UNESCO sebagai Sarana Pencegahan Penyebaran Hoaks, Jurnal Litbang Provinsi Jawa Tengah, 16(1), 59-66. http://ejournal.bappeda.jatengprov.go.id/index.php/jurnaljateng/arti cle/view/762.

Hidayat, A. (2018). Dakwah di Kalangan masyrakat Transmigran, Nalar: Jurnal Peradaban dan Pemikiran Islam, 2 (2): 75-88. DOI: https://doi.org/10.23971/njppi.v2i2.963.

Ikhsan, M. (2021, Pebruari 25). Riset: Netizen di Indonesia Paling Tak Sopan se-Asia Tenggara. Retrieved Juni 7, 2021, from CNN Indonesia: https://www.cnnindonesia.com/teknologi/20210225115954-185610735/ riset-netizen-di-indonesia-paling-tak-sopan-se-asia-tenggara

Ilaihi, W. (2010). Komunikasi Dakwah. Bandung: Remaja Rosdakarya.

Juditha, C. (2019). Literasi Informasi MelawanHoaks Bidang Kesehatan di Komunitas Online, Jurnal Ilmu Komunikasi, 16(1), 77-90. DOI: https://doi.org/10.24002/jik.v16i1.1857.

Khosiah, F., \& Rohmiati, Y. (2019). Kontrol Informasi Publik terhadap Fake News dan Hate Speech oleh Aliansi Jurnalis Independen, Anuva, 3 (3): 291-302. DOI: 10.14710/anuva.3.3.291-302.

Legionosuko, T., \& Harnowo, S. (2017). Dinamika Fake News atau Hoaks sebagai Sumber Konflik Horizontal pada Pilkada Provinisi DKI Tahun 2017, Jurnal Damai dan Resolusi Konflik, 3 (3): 111-135. http://jurnalprodi.idu.ac.id/index.php/DRK/article/view/186.

Lokananta, A. C., \& Herlina, M. (2018). Dampak Informasi Hoaks di Media Sosial terhadap Tingkat Konflik dan Sikap pada Remaja, Promedia, 4 (2): 100113. DOI: https://doi.org/10.52447/promedia.v4i2.1257.

Maulana, L. (2017). Kitab Suci dan Hoax: Pandangan Al-QUr'an dalam Menyikapi Berita Bohong, Wawasan: Jurnal Ilmiah Agama dan Sosial Budaya, 2 (2): 209-222. DOI: https://doi.org/10.15575/jw.v2i2.1678.

Mazaya, V. (2019). Cyberdakwah sebagai Filter Penyebaran Hoaks, Islamic Communication Journal, 4 (1): 14-25. DOI : 10.21580/icj.2019.4.1.3588. 
Mukarom, Z. (2020). Islamic Da'wah in Indsutrial Society: Study on Employees of PT Indonrama Synthetics Tbk Purwakarta, Ilmu Dakwah: Academic Journal for Homiletic Studies, 14 (1): 1-20. DOI: https://doi.org/10.15575/idajhs.v14i1.8693.

Mukarom, Z., Rosyidi, I., \& Muzzammil, F. (2020). Mediatization of Da'wah in Disruption Era: Study of Islamic Da'wah in Social Media, American Journal of Humanities and Social Sciences Research (AJHSSR), 4 (9): 190-202. http://digilib.uinsgd.ac.id/37681/.

Muzzammil, F. (2021). Dimensi Dakwah Islam dalam Budaya Nyepuh, Hanifiya: Jurnal Studi Agama-Agama, 4 (1): 1-14. https://journal.uinsgd.ac.id/index.php/hanifiya/article/view/10964/ 5491.

Nasution, M. A. (2017). Hoaks sebagai Bentuk Hudud Menurut Hukum Islam, $\begin{array}{llll}\text { Yurisprudentia, } & 3 & \text { (1): } & \text { 16-32. }\end{array}$ https://doi.org/10.24952/yurisprudentia.v3i1.677.

Octalia, E., \& Mughni, A. (2018). Dakwah Melawan Hoaks Menuju Literasi Media, Ath-Thariq: Jurnal Dakwah dan Komunikasi, 2 (2): 373-387. DOI: https://doi.org/10.32332/ath_thariq.v2i2.1289.

Oktovianny, L. (2020). Budaya Literasi (Baca-Tulis) dan Hoaks di Era Disrupsi, E-Prosiding Seminar Nasional Pekan Chairil Anwar, 1(1), 42-46. https://jurnal.unej.ac.id/index.php/prosiding/article/view/19969.

Pohan, S., Jamil, A., \& Andyna, C. (2017). Pesan-Pesan Dakwah dalam Kaus Mosclot, Al-Balagh, 1 (2): 253-266. http://jurnal.uinsu.ac.id/index.php/balagh/article/view/1472/1201.

Ramayanti, R., \& Sa'diyah, L. (2017). Peranan Literasi Media Digital dalam Mencegah Penyebaran Hoaks, Baitul al 'Ulum: Jurnal Ilmu Perpustakaan dan Informasi, 1(1), 1-15. https://doi.org/10.30631/baitululum.v1i0.15.

Rustandi, R. (2019). Cyberdakwah: Internet sebagai Media Baru dalam Sistem Komunikasi Dakwah Islam, Nalar: Jurnal Peradaban dan Pemikiran Islam, 3 (2): 84-95. DOI: https://doi.org/10.23971/njppi.v3i2.1678.

Rustandi, R., \& Muchtar, K. (2020). Analisis Framing Kontra Narasi Terorisme dan Radikalisme di Media Sosial (Studi Kasus pada Akun (a)dutadamaijabar), Jurnal Komunikatif, 9(2), 134-153. DOI: https://doi.org/10.33508/jk.v9i2.2698.

Septanto, H. (2018). Pengaruh Hoaks dan Ujaran Kebencian sebuah Cyber Crime dengan Teknologi Sederhana di Kehidupan Sosial Masyarakat, Kalbiscentia: Jurnal Sains dan Teknologi, 5 (2): 157-162.

Silalahi, R. R., \& Sevilla, V. (2020). Rekonstruksi Makna Hoaks Di Tengah Arus Informasi Digital, Global Komunika, 1 (1): 8-16. 
https:/ / ejournal.upnvj.ac.id/index.php/GlobalKomunika/article/vie w/1722.

Thadi, R., \& Mukhlizar. (2021). Literasi Dakwah di Era Post Truth, Joiscom: Journal of Islamic Communication, 2 (1): 31-28. http://jurnal.umb.ac.id/index.php/joiscom/article/view/1546.

Tsaniyah, N., \& Juliana, K. A. (2019). Literasi Digital sebagai Upaya Menangkal Hoaks di Era Disrupsi, Al-Balagh: Jurnal Dakwah dan Komunikasi, 4 (1): 121-140. DOI: 10.22515/balagh.v4i1.1555.

Wahid, A. (2017). Hoaks dalam Perspektif Islam, Syaikhuna: Jurnal Pendidikan dan $\begin{array}{llll}\text { Pranata Islam, } & 8 & \text { (2): } & \text { 190-197. }\end{array}$ http://ejournal.kopertais4.or.id/madura/index.php/syaikhuna/article /view/3160. 